\title{
Macro, Meso and Micro Perspectives of Technology Transfer
}

James A. Cunningham

Newcastle Business School, Northumbria University, Newcastle upon Tyne, UK

Paul O'Reilly

Technological University Dublin, paul.oreilly@tudublin.ie

Follow this and additional works at: https://arrow.tudublin.ie/buschmancon

Part of the Electrical and Computer Engineering Commons

\section{Recommended Citation}

Cunningham, J.A. \& O'Reilly, P. Macro, Meso and Micro Perspectives of Technology Transfer. The Journal of Technology Transfer, vol. 43, no. 3, pg. 545-557. doi:10.1007/s10961-018-9658-4

This Article is brought to you for free and open access by the School of Management at ARROW@TU Dublin. It has been accepted for inclusion in Conference Papers by an authorized administrator of ARROW@TU Dublin. For more information, please contact arrow.admin@tudublin.ie, aisling.coyne@tudublin.ie,gerard.connolly@tudublin.ie.

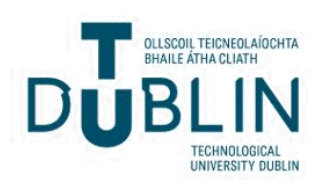




\title{
Macro, meso and micro perspectives of technology transfer
}

\author{
James A. Cunningham ${ }^{1} \cdot$ Paul O'Reilly ${ }^{2}$
}

Published online: 23 February 2018

(c) The Author(s) 2018. This article is an open access publication

\begin{abstract}
Over the last few decades research into the different aspects of technology transfer has grown significantly that has taken in the main a macro perspective. This research has created a body of knowledge and an evidence base that has contributed original insights in developing the field and also has shaped policymaking and practice. Within the field there is a growing focus on meso and micro aspects of technology transfer and a growing interest in for example role individual actors such as scientists, principal investigators policy makers, TTO actors, supporting institutions and functions such as universities, professional research organizations, technology and knowledge transfer offices. This research is unearthing fine-grained nuances and insights that provide further evidence of how technology transfer activities are shaped and evolve in different geographical and organizational contexts. The purpose of this special issue is to provide a further understanding of macro, meso and micro perspectives of technology transfer and to provide an agenda for further research that blends these multi-level perspectives of technology transfer.
\end{abstract}

Keywords Technology transfer - Scientists - Technology transfer offices - Universities · R\&D $\cdot$ Entrepreneurial ecosystems $\cdot$ Academic spin-off $\cdot$ Start-ups

JEL Classification $\quad \mathrm{O} 25 \cdot \mathrm{O} 30 \cdot \mathrm{O} 32 \cdot \mathrm{O} 31 \cdot \mathrm{O} 38 \cdot \mathrm{M} 1 \cdot \mathrm{M} 00 \cdot 126$

James A. Cunningham

james.cunningham@northumbria.ac.uk

Paul O’Reilly

paul.oreilly@dit.ie

1 Newcastle Business School, Northumbria University, Newcastle upon Tyne, UK

2 Dublin Institute of Technology, Dublin, Ireland 


\section{Introduction}

There has been a long tradition of macro perspectives of technology transfer that have laid the empirical and theoretical foundations within the field. These draw from a range of different disciplines such as economics, management, innovation, public policy, strategic management and entrepreneurship. At a macro level this has generated evolving perspectives on for example the mechanisms, measurement, evaluation and effectiveness of technology transfer (see Autio and Laamanen 1995; Bozeman 2000; Cutler 1988; Rasmussen and Rice 2011; Phillips 2002; Siegel et al. 2007; Winebrake 1992). At the macro perspective researchers, endeavors have tackled some of the fundamental questions in relation technology transfer that has and continues to have a relevance to such individual actors involved in technology transfer such as scientists, R\&D specialists, CEOs, policy makers etc. These macro perspectives have also focused on technology transfer mechanisms (formal and informal) and methods (see Amesse and Cohendet 2001; Bradley et al. 2013; Cutler 1989; Grimpe and Fier 2010; Gilsing et al. 2011; Lee and Win 2004; Molas-Gallart 1997). Moreover, this macro perspective has also focused on the effectiveness of policy instruments designed to support effective technology transfer at national or regional levels or targeted at specific industry sectors (Contractor and Sagafi-Nejad 1981; Rothwell and Dodgson 1992; Worrell et al. 2001).

A particular macro focus of empirical studies have centred on the Bayh-Dole Act 1980 that have evaluated the impact of this US legislation on shaping and driving technology transfer from universities to industry (Grimaldi et al. 2011; Kenney and Patton 2009; Mowery 2005, 2011; Mowery et al. 2001 Mowery and Sampat 2004; Nelson 2001). Other policy and context orientated studies have empirically investigated the impact of other policy initiatives in the US and other contexts such as European countries (see Adams and Link 2017; Becher and Kuhlmann 2012; Breschi et al. 2007; Cunningham and Link 2015, 2016; Geuna and Rossi 2011; Haeussler and Colyvas 2011; Hall et al. 2001; Hall and Link 2015; Hülsbeck et al. 2013; Link and Scott 2013; Jacob et al. 2003).

Studies have focused at the meso level with a particular focus on supporting institutions. Technology transfer offices have been a particular focus of empirical studies at both the meso and micro levels (see Algieri et al. 2013; Chapple et al. 2005; Geoghegan et al. 2015; Secundo et al. 2017; Siegel et al. 2003; O'Kane et al. 2015). The role incubators, accelerators and graduate entrepreneurship has become a growing area of focus among researchers (see Birch et al. 2017; Kolympiris and Klein 2017; Larsson et al. 2017; Lindholm Dahlstrand and Politis 2013; Mian 1996; McAdam et al. 2006; Redondo et al. 2017; Wright et al. 2017). Moreover emerging growing body of research on science parks have taken multi-level perspectives of technology transfer (see Hobbs et al. 2017).

Micro perspectives of technology transfer have focused on a variety of themes and are growing within the field using different discipline perspectives (see Albats et al. 2017; Cusumano and Elenkov 1994). Such studies have focused on for example the use of technology transfer offices (Muscio 2010), cultural differences (Lin and Berg 2001); institutional dimensions of R\&D collaborations (Bjerregaard 2010), motivations (Cunningham et al. 2016a; D'este and Perkmann 2011; Hayter 2017), communications (Barnes et al. 2002; Plewa et al. 2013), time allocations (Ponomariov and Boardman 2008) and barriers to university collaboration (Cunningham et al. 2014; Hall et al. 2001; O'Reilly and Cunningham 2017; O'Kane et al. 2017). Over the last decade there have been a growing micro level focus on better understanding technology transfer through the experiences of individual actors involved in the technology transfer process such as academic entrepreneurs 
(Bercovitz and Feldman 2008; Mosey and Wright 2007; Miller et al. 2017) scientists (Link et al. 2007) star scientists (Baba et al. 2009; Meyer 2006), principal investigators (Cunningham et al. 2016a; Cunningham et al. 2017a; Cunningham et al. 2018; Del Giudice et al. 2017; Menter 2016), technology entrepreneurs and graduate students (see Evers et al. 2014; Guerrero et al. 2018; Hayter et al. 2017; RezaeiZadeh et al. 2017; Watson and McGowan 2017; Watson et al. 2018).

Different conceptual and theoretical perspectives have emerged that have embraced, encompassed and shaped perspectives with respect technology transfer in a broader economic and social context that attempts to incorporate the multiple layers of macro, meso and micro perspectives. These have shaped the ways researchers situate, analyze and interpret their data in order to contribute to the growing body of knowledge and evidence base of technology transfer. Perspectives such as the triple and quadruple helix (see Carayannis et al. 2018; Etzkowitz and Leydesdorff 2000; McAdam and Debackere 2018; Miller et al. 2018); entrepreneurial ecosystems (Audretsch and Belitski 2017; Pitelis 2012; Spigel 2017), clusters (Rocha 2004; Spigel and Harrison 2017), public sector entrepreneurship (Leyden and Link 2015; Leyden 2016) provide competing and complimentary perspectives that attempt to provide a multi-layer perspective that can enable both a synthesis and an interrogation of technology transfer ranging from macro to the micro level.

\section{Themes and contributions}

We have divided the selected papers in this special issue into main themes. The first theme focuses on papers that take a macro perspective on different aspects of technology transfer and they after pertinent and very relevant policy implications and considerations. The second theme of papers focus on either meso or micro foundational perspectives of technology transfer.

\subsection{Macro perspectives of technology transfer}

The first paper of Lehmann and Menter (2017) addresses a fundamental macro issue of how a policy initiative - in this case cluster policy promoted by the German government-has performed taking a particular regional focus. At a macro level, cluster policy as a policy initiative has been favored by policy makers as an effective policy response to generating additional economic wealth. The assumption is that such a policy response has a positive impact on different actors and at national, regional and local levels. As Lehmann and Menter (2017) state the conventional thinking is that 'it pays' for policy makers to adopt this policy approach. The results of their comprehensive and robust study highlight the direct and indirect effects of such as policy initiative and how this shapes cluster policy. Interestingly they highlight the important and key role that universities play in creating new knowledge at a regional level that can be exploited through technology transfer mechanisms and commercialized by firms or entrepreneurs in the region. Consequently, this has direct beneficial outcome with respect to regional economic performance, and as they suggest, it requires appropriate incentives to ensure that universities fully engage with cluster policy initiatives, as well as appropriate technology transfer infrastructure at the regional level. Lehmann and Menter (2017) highlight the necessity for policy makers to consider the direct and indirect impacts of policy at the meso and micro levels as well as the potential unintended consequences. This study highlights the need for contextually and 
appropriately designed policy instruments to support effective technology transfer is essential that is ambitious in it goals, but also addresses the fundamental tangible or intangible barriers that actors and supporting institutions experience. Such policy initiatives need to achieve better outcomes than the status quo and such outcomes can and need to be sustained over the long term, without the directional support of Government policy.

A favored policy response at the macro level by policy makers is focused on incentizing or subsidizing R\&D investment that are exploiting university knowledge or in firm activities. Previous studies have highlighted how effective R\&D subsidies can positively impact on private firms. Set in the US context and focusing on the Advanced Technology Programme, Smith et al. (2017) paper deals with a challenging and fundamental question in relation to the long-term survival effects on firms that have received government support. While previous studies have evaluated and analyzed the impact of government/federal programmes in the US, none have examined the long-term effect, which is a unique aspect of this paper. Smith et al. (2017), taking this long-term, view find receiving funding under this programme has a positive and significant effect on firm survival. The results of this study provide essential evidence in relation to the long-term effects of a subsidized R\&D programme on firms. It also reaffirms, as does the Lehmann and Menter (2017) paper, the need for policy makers to design appropriate technology transfer programmes or policies that not alone have aggregated short to medium term beneficial and positive effects, but that these should and can be extended into the long-term. While the strategic intent of policy makers in designing such policies or programmes is to effect positive outcomes over the long-term, the temporal pressures mean short term effects needs to be delivered relatively quickly to demonstrate the success of such initiatives. This paper paves the way for other studies of different technology transfer programmes and policies that examine their effect at the meso and micro level over the long-term.

Another aspect of macro perspectives is the organization, structuring and co-ordination of public funding to support the exploitation of results for commercial and societal beneficiaries. The European Union's Framework programme provides the setting for our third paper by Nepelski and Piroli (2017) who focus on the organizational diversity and innovation potential of EU funded research programmes, which are collaborative in nature and design. To secure funding focused on dedicated research themes it typically requires collaboration activities between academics and industry partners-SMEs and MNCs across EU Member States. This paper addresses a key and neglected issue of what is the appropriate combination of collaborators to realize the innovative potential of publicly funded projects. The findings of Nepelski and Piroli (2017) highlight the importance and effect that consortium design and incentives have on realizing positive and beneficial effects. This also points to the need for micro level studies that specifically focus on publicly funded collaborative research project dynamics, research management, capabilities and leadership. Moreover, this paper further illustrates the need for firms to carefully consider the size, mix of firms and their capabilities when they are seeking to commercialize knowledge through technology transfer mechanisms. Consequently, the findings of this study similar to Smith et al. (2017) highlight the need for policy makers to consider carefully the design of policy programmes and policies that provides beneficial support to targeted actors and activities, but also reflects the diversity of needs and intent of actors and supporting institutions.

Our final macro level paper by Nicotra et al. (2017) proposes a framework to test the causal effects of entrepreneurial ecosystem. Effective entrepreneurial ecosystem enables technology transfer between actors and institutions. The authors conceptualize their framework into eco-factors and eco-outputs as a way of overcoming the deficits with respect to measuring entrepreneurial ecosystems. Interestingly, they argue that there is a need to 
validate causal relations within entrepreneurial ecosystems beyond regions or territories that have been the focus of much empirical attention such as Silcon Valley. Such validation using data sources across different territories to test causal effects is necessary to further evolve our theoretical and empirical understanding of the effectiveness and development of entrepreneurial ecosystems irrespective of a geographic territory. One of the dangers is the blind imitation and replication of programmes, policies and initiatives from successful entrepreneurial ecosystems territories to others without a deeper understanding of causal effects. For policy makers this framework provides a more holistic conceptualization as well as potential data sources to test causal effects. Its application and results in terms of testing this framework have the potential to highlight the deficits as well strengths between programmes and entrepreneurial results. Moreover, testing of the framework and the insights generated can provide entrepreneurial ecosystem actors and supporting organizations with an understanding of how effective their ecosystem is. Moreover, it can provide some evidence as to what potential policy and programme interventions are appropriate and essential for the sustainability of a entrepreneurial ecosystem in a particular teerro.

\subsection{Meso and micro perspectives of technology transfer}

The second set of papers for this special issue focus on meso and micro level themes of technology transfer includes university start-up interactions, academic spin-offs' entrepreneurial teams, composition and interactions and digital start-ups, education attainment and equity milestones. Our first paper by van Stijn et al. (2017) focuses on university start-up interaction using data from Route 128 in Boston, MA, USA. They identified 14 university start-up interaction practices. The findings of this study provide key insights into how universities could better support start-ups, particularly with respect to market development as this knowledge transfer is essential to market development of an academic start-up. Furthermore, the findings challenge universities on and those within universities on how best to support academic start-ups. Legitimately the authors argue that the needs of start-ups near to market may be better met with programmes and supports outside the university environment. This raises an interesting strategy question for universities, whether they enhance their supports and provision in near market start-ups or instead focus exclusively on science based start-ups. Moreover, the findings of this study means that universities need to make a clear strategic decision on what is the scope of their start-up provision. It also means they need to have sufficient organisational flexibility in order to meet the current and future anticipated and unanticipated needs of start-ups and their founders.

Ben-Hafaïedh et al. (2017) paper focuses on academic spin-off's entrepreneurial team composition and performance based on Italian data. The question of near-to-market issues similar to the Van Stijn et al. (2017) is raised in this paper with respect to academic spinoffs. The findings provide some interesting implications and challenges for those supporting academic spin-offs. For example, how do universities encourage academics to be involved in academic spin-offs and what practical and pragmatic approaches can academics adopt or use at the meso and micro levels to ensure the best entrepreneurial team configuration to accelerate the technology development that really enhances and increases the probability of their spin-off being bought out? The study finds that the dual configuration of academic and practitioner entrepreneurial team configuration provides the basis for the most effective commercial performance. From a macro or meso level what policy instruments and programmes can truly encourage and support such team configurations. For academics, this study suggests the need for them to be open to considering commercial collaborations with practitioners in order to overcome near-to-market issues, to accelerate the 
spin-off development and provide the commercial basis that is necessary to drive spin-off performance. For practitioners, the dual configuration offers an effective means of ensuring commercial performance. The challenge for practitioners is selecting the potential academic spin-offs that have real commercial potential and the openness among the academic founders in pursuing a dual entrepreneurial team configuration to ensure commercial success.

University spin-offs is the focus of Kolb and Wagner's (2017) paper that is based on a single university setting where they developed a framework of needs. The authors also identified the importance of support structures for the four categorises of spin-out groups that they identified. What is clear from this study is universities need to provide a broad range of support structures to provide the appropriate support to university spin-offs given the categories identified in this study. The demand for these support structures varies and as Kolb and Wagner (2017) note, this requires universities to be flexible with the provision of appropriate support structures to support their heterogeneity. This raises a strategic question for universities and TTOs regarding how best to attain the balance between generic and more tailored support structures, as this has implications for resources, organisational structures and the professional technology transfer skill set required to support such variety of university spin-offs. At a meso level the findings of this study provide some empirical evidence that contributes to a wider debate with respect to the role and purpose of TTOs, particularly with respect to standardization and specialization This micro study, set in a single university context, yields the real rich nuances that underpins technology transfer. Furthermore, the micro perspectives of university spin-offs in this paper provide necessary and valuable insights that warrant further studies by extending such research into other institutional and geographical contexts using a micro level.

Our final paper in this special issue by Ratzinger et al. (2017), focuses on the impact of digital start-up founders' higher education on reaching equity investment milestones taking a human capital perspective. With a large sample of digital start-ups this study has both micro and meso level implications, as well as macro, particularly with respect to levels of societal educational attainment. For students the findings of this study affirms the beneficial value of higher education attainment and the necessity of having the openness, capacity and capability to engage and interact with students from other disciplines. For universities the study raises some relevant issues with respect to entrepreneurship educational provision and the skills development component of degree programmes irrespective of discipline or subject areas. In practical terms, this requires universities to take a strategic view as to the importance of university wide entrepreneurship education provision, the nature of provision-core or extra curricular-and how broad as well as specific skills are nurtured and developed by students through the progression in their degree programmes. For investors in start-ups the study provides further evidence of the needs to take into consideration the educational attainment and background of founders of digital start-ups.

\section{Proposed research agenda}

\subsection{Meso level: evaluative country and cross country comparison studies}

What is evident from the studies of technology transfer to date, irrespective of level of analysis, is that there is dominant focus on North America. There is a need for further evaluative studies a country level of technology transfer at macro and meso levels. Studies 
to date of the US technology transfer system, programmes and policies provide researchers with robust methodological and evaluative approaches to undertake such studies. Such country level studies not alone add to the existing body of knowledge at a macro level but can illuminate the variety as well as commonalities of effect of national programs and policies. At a micro level more country studies are needed to better understand the nuanced behaviours, motivators, influences, approaches of individual actors such as technology and knowledge transfer.

There has been a lack of cross country comparison studies within the field that are evaluative. This is understandable given the challenges of concluding large scale cross countries comparison studies. Particularly at the macro level, these are necessary from evolving the body of knowledge within the field but also to provide policy makers with further evidence that contribute to more effective policy and programme support of technology transfer. Given the challenges involved in large scale cross country comparison studies there is a need to create them in a way that it can be scaled, accessed and shared as well having a longitudinal dimension.

Linked to the need for evaluative and comparison studies is the need for further studies that examines, the policy and public sector entrepreneurship replication between different countries. For example, some European countries have replicated aspects of the US SBIR programme. Such studies would provide further insights into the barriers and challenges of policy and public sector entrepreneurship replication that would be beneficial to national, regional and local technology transfer policy making processes and would unearth specific contextual adoption.

\subsection{Meso level studies}

To further, develop the field there is a need for researchers to concentrate more research effort in focusing on the meso level of technology transfer. From our perspective, there is a need for further studies that specifically examine the role, behaviours and actions of supporting actors in the technology transfer process. This could range from for example regional public authorities, national funding agencies, incubators and hubs that are publicly and privately funded to technology transfer offices. Assumptions are made about the role and effects that these supporting institutions have on influencing and shaping technology transfer. Macro and micro level factors shape how meso level supporting actors support the technology transfer process in terms of incentives, supports and the how they organise themselves to realise their own targets and objectives within a wider technology transfer system.

Another potential area for meso level studies is examining the regional and industry context of technology transfer. While there have been many empirical studies that have focused on certain locations such as Silicon Valley there is a need to focus on regions where there are variations in the economic, social and technological endowments and how this effects technology transfer. Moreover, this also opens up opportunities for comparative studies of regions in different continents and also allows for focus on different types of firms such as multinational firms, small and medium enterprises, non for profit firms and publicly owned semi state bodies. In addition, there is a need to expand at the meso level the industry sectors on which empirical studies are based as there is a narrow concentration of existing studies on certain industries (Cunningham et al. 2017b). 


\subsection{Micro level perspectives: individual actors behaviours and actions}

There have been a growth of micro level studies within the technology transfer field, with an increasing number of researchers using a unit of analysis that is focused on the individual actor in the technology transfer process. Studies to date have focused on scientists, faculty members and principal investigators. These studies have unearthed interesting perspectives and practices with respect to individual actor, behaviours and action with respect to technology transfer. Some further micro level studies are needed that examine more of the antecedent factors that shape individual perspectives and behaviours prior to engaging with a technology transfer process. Moreover, more micro studies are needed with respect to the specific technology transfer mechanisms such as licensing and specific individual actors.

Future studies at the micro level must expand the unit of analysis at the individual level to include other actors such as TTO professionals, regional or national policy programme or policy directors, research officers in funding agencies and within higher education institutions, as well as private sector based scientists and principal investigators. To compliment an expansion of individual actors studies should also seek to focus on career stage, professional experience, gender and types of institutional supports. In addition, individual analysis could be expanded further to examine the individual recipient decision maker technology transfer from universities, publicly funded research organisation or other organisations.

\section{Conclusions}

In this introductory paper for this special issue, we have reviewed some of the issues with respect to macro, meso and micro perspectives of technology transfer. We then have outlined and discussed the implications of the eight selected papers. We concluded with some potential avenues for future studies for researchers of technology transfer using macro, meso and micro level perspectives.

To advance studies of technology transfer irrespective of level of focus, researchers should use the full range of methodological and data collection approaches and to be more experimental in their research design of studies of technology transfer. Researchers should consider developing international, cross-sectoral and longitudinal datasets that allows for cross-country comparisons and potentially multi-level analysis that further advances the field, which can provide further evidence for policy makers, recipients of technology transfer and potentially enhance their decision making.

Opportunities exist to expand the context of studies in terms of institutional and domain settings. In the main, studies have focused on technology transfer in higher educational settings, but as other types of organisations are getting more involved in the technology transfer process these should also be the focus of further studies. While the predominant domain focus of empirical studies of technology transfer have been science, engineering and technology there is a need to expand the domain focus to arts, humanities and social sciences at the macro, meso and micro levels. Business schools should also be a focus for meso and micro level studies of technology transfer. Finally, future studies of technology transfer irrespective of level of analysis should consider the recipient organisation perspectives of technology transfer as well as situations where technology transfer has failed. Failure of technology transfer is another potential and fruitful research avenue for future research but has largely remained under explored. 
Acknowledgements We would like to thank Professor Albert N. Link for his support in developing this special issue and to all the reviewers for their timely and constructive reviews that have shaped the individual papers in this special issue. We would like to thank all those who contributed to the organisation of the Technology Transfer Society Conference held at Dublin Institute of Technology in 2015 which these papers were selected for this special issue. James A. Cunningham wishes to acknowledge the funding support of the authors wish to acknowledge funding support of Science Foundation Ireland (SFI) and co-funding under the European Regional Development Fund under Grant No. 13/RC/2073.

\section{Compliance with ethical standards}

Conflict of interest The authors declare that they have no conflict of interest.

Open Access This article is distributed under the terms of the Creative Commons Attribution 4.0 International License (http://creativecommons.org/licenses/by/4.0/), which permits unrestricted use, distribution, and reproduction in any medium, provided you give appropriate credit to the original author(s) and the source, provide a link to the Creative Commons license, and indicate if changes were made.

\section{References}

Adams, J. A., \& Link, A. L. (2017). The structure and performance of U.S. research joint ventures: Inferences and implications from the Advanced Technology Program. Economics of Innovation and New Technology. https://doi.org/10.1080/10438599.2017.1376169.

Albats, E., Fiegenbaum, I., \& Cunningham, J. A. (2017). A micro level study of university industry collaborative lifecycle key performance indicators. The Journal of Technology Transfer. https://doi. org/10.1007/s10961-017-9555-2.

Algieri, B., Aquino, A., \& Succurro, M. (2013). Technology transfer offices and academic spin-off creation: The case of Italy. The Journal of Technology Transfer, 38(4), 382-400.

Amesse, F., \& Cohendet, P. (2001). Technology transfer revisited from the perspective of the knowledgebased economy. Research Policy, 30(9), 1459-1478.

Audretsch, D. B., \& Belitski, M. (2017). Entrepreneurial ecosystems in cities: Establishing the framework conditions. The Journal of Technology Transfer, 42(5), 1030-1051.

Autio, E., \& Laamanen, T. (1995). Measurement and evaluation of technology transfer: Review of technology transfer mechanisms and indicators. International Journal of Technology Management, 10(7-8), 643-664.

Baba, Y., Shichijo, N., \& Sedita, S. R. (2009). How do collaborations with universities affect firms' innovative performance? The role of "Pasteur scientists" in the advanced materials field. Research Policy, 38(5), 756-764.

Barnes, T., Pashby, I., \& Gibbons, A. (2002). Effective university-industry interaction: A multi-case evaluation of collaborative R\&D Projects. European Management Journal, 20(3), 272-285.

Becher, G., \& Kuhlmann, S. (Eds.). (2012). Evaluation of technology policy programmes in Germany (Vol. 4). Berlin: Springer.

Ben-Hafaïedh, C., Micozzi, A., \& Pattitoni, P. (2017). Academic spin-offs' entrepreneurial teams and performance: A subgroups approach. The Journal of Technology Transfer. https://doi.org/10.1007/s1096 1-017-9623-7.

Bercovitz, J., \& Feldman, M. (2008). Academic entrepreneurs: Organizational change at the individual level. Organization Science, 19(1), 69-89.

Birch, C., Lichy, J., Mulholland, G., \& Kachour, M. (2017). An enquiry into potential graduate entrepreneurship: Is higher education turning off the pipeline of graduate entrepreneurs? Journal of Management Development, 36(6), 743-760.

Bjerregaard, T. (2010). Industry and academia in convergence: Microinstitutional dimensions of R\&D collaboration. Technovation, 30(2), 100-108.

Bozeman, B. (2000). Technology transfer and public policy: A review of research and theory. Research Policy, 29(4), 627-655.

Bradley, S. R., Hayter, C. S., \& Link, A. N. (2013). Models and methods of university technology transfer. Foundations and Trends ${ }^{\circledR}$ in Entrepreneurship, 9(6), 571-650.

Breschi, S., Lissoni, F., \& Montobbio, F. (2007). The scientific productivity of academic inventors: New evidence from Italian data. Economics of Innovation and New Technology, 16(2), 101-118. 
Carayannis, E. G., Grigoroudis, E., Campbell, D. F., Meissner, D., \& Stamati, D. (2018). The ecosystem as helix: An exploratory theory-building study of regional co-opetitive entrepreneurial ecosystems as Quadruple/Quintuple Helix Innovation Models. R\&D Management, 48(1), 148-162.

Chapple, W., Lockett, A., Siegel, D., \& Wright, M. (2005). Assessing the relative performance of UK university technology transfer offices: Parametric and non-parametric evidence. Research Policy, 34(3), 369-384.

Contractor, F. J., \& Sagafi-Nejad, T. (1981). International technology transfer: Major issues and policy responses. Journal of International Business Studies, 12(2), 113-135.

Cunningham, J. A., \& Link, A. N. (2015). Fostering university-industry R\&D collaborations in European Union countries. International Entrepreneurship and Management Journal, 11(4), 849-860.

Cunningham, J. A., \& Link, A. N. (2016a). Exploring the effectiveness of research and innovation policies among European Union countries. International Entrepreneurship and Management Journal, 12(2), 415-425.

Cunningham, J. A., Mangematin, V., O'Kane, C., \& O'Reilly, P. (2016b). At the frontiers of scientific advancement: The factors that influence scientists to become or choose to become publicly funded principal investigators. The Journal of Technology Transfer, 41(4), 778-797.

Cunningham, J. A., Menter, M., \& O'Kane, C. (2018). Value creation in the quadruple helix: A micro level conceptual model of principal investigators as value creators. $R \& D$ Management, 48(1), 136-147.

Cunningham, J. A., Menter, M., \& Wirsching, K. (2017a). Entrepreneurial ecosystem governance: A principal investigator-centered governance framework. Small Business Economics, 1-18.

Cunningham, J. A., Menter, M., \& Young, C. (2017b). A review of qualitative case methods trends and themes used in technology transfer research. The Journal of Technology Transfer, 42(4), 923-956.

Cunningham, J., O'Reilly, P., O'Kane, C., \& Mangematin, V. (2014). The inhibiting factors that principal investigators experience in leading publicly funded research. The Journal of Technology Transfer, $39(1), 93-110$.

Cusumano, M. A., \& Elenkov, D. (1994). Linking international technology transfer with strategy and management: A literature commentary. Research Policy, 23(2), 195-215.

Cutler, R. S. (1988). Survey of high-technology-transfer mechanisms in Japan and the USA. The Journal of Technology Transfer, 13(1), 42-48.

Cutler, R. S. (1989). A comparison of Japanese and US high-technology transfer practices. IEEE Transactions on Engineering Management, 36(1), 17-24.

D'este, P., \& Perkmann, M. (2011). Why do academics engage with industry? The entrepreneurial university and individual motivations. The Journal of Technology Transfer, 36(3), 316-339.

Del Giudice, M., Nicotra, M., Romano, M., \& Schillaci, C. E. (2017). Entrepreneurial performance of principal investigators and country culture: Relations and influences. The Journal of Technology Transfer, 42(2), 320-337.

Etzkowitz, H., \& Leydesdorff, L. (2000). The dynamics of innovation: From national systems and "Mode 2" to a triple helix of university-industry-government relations. Research Policy, 29(2), 109-123.

Evers, N., Cunningham, J., \& Hoholm, T. (2014). Technology entrepreneurship: Bringing innovation to the marketplace. Basingstoke: Palgrave Macmillan.

Geoghegan, W., O'Kane, C., \& Fitzgerald, C. (2015). Technology transfer offices as a nexus within the triple helix: The progression of the university's role. International Journal of Technology Management, 68(3-4), 255-277.

Geuna, A., \& Rossi, F. (2011). Changes to university IPR regulations in Europe and the impact on academic patenting. Research Policy, 40(8), 1068-1076.

Gilsing, V., Bekkers, R., Freitas, I. M. B., \& Van der Steen, M. (2011). Differences in technology transfer between science-based and development-based industries: Transfer mechanisms and barriers. Technovation, 31(12), 638-647.

Grimaldi, R., Kenney, M., Siegel, D. S., \& Wright, M. (2011). 30 years after Bayh-Dole: Reassessing academic entrepreneurship. Research Policy, 40(8), 1045-1057.

Grimpe, C., \& Fier, H. (2010). Informal university technology transfer: A comparison between the United States and Germany. The Journal of Technology Transfer, 35(6), 637-650.

Guerrero, M., Urbano, D., Cunningham, J. A., \& Gajón, E. (2018). Determinants of graduates' start-ups creation across a Multi-campus Entrepreneurial University: The case of Monterrey Institute of Technology and Higher Education. Journal of Small Business Management, 56(1), 150-178.

Haeussler, C., \& Colyvas, J. A. (2011). Breaking the ivory tower: Academic entrepreneurship in the life sciences in UK and Germany. Research Policy, 40(1), 41-54.

Hall, M. J., \& Link, A. N. (2015). Technology-based state growth policies: The case of North Carolina's Green Business Fund. The Annals of Regional Science, 54(2), 437-449. 
Hall, B. H., Link, A. N., \& Scott, J. T. (2001). Barriers inhibiting industry from partnering with universities: Evidence from the advanced technology program. The Journal of Technology Transfer, 26(1), 87-98.

Hayter, C. S., Lubynsky, R., \& Maroulis, S. (2017). Who is the academic entrepreneur? The role of graduate students in the development of university spinoffs. The Journal of Technology Transfer, 42(6), 1237-1254.

Hobbs, K. G., Link, A. N., \& Scott, J. T. (2017). Science and technology parks: An annotated and analytical literature review. The Journal of Technology Transfer, 42(4), 957-976.

Hülsbeck, M., Lehmann, E. E., \& Starnecker, A. (2013). Performance of technology transfer offices in Germany. The journal of technology transfer, 38(3), 199-215.

Jacob, M., Lundqvist, M., \& Hellsmark, H. (2003). Entrepreneurial transformations in the Swedish University system: The case of Chalmers University of Technology. Research Policy, 32(9), 1555-1568.

Kenney, M., \& Patton, D. (2009). Reconsidering the Bayh-Dole Act and the current university invention ownership model. Research Policy, 38(9), 1407-1422.

Kolb, C., \& Wagner, M. (2017). How university spin-offs differ in composition and interaction: A qualitative approach. The Journal of Technology Transfer. https://doi.org/10.1007/s10961-017-9629-1.

Kolympiris, C., \& Klein, P. G. (2017). The effects of academic incubators on university innovation. Strategic Entrepreneurship Journal, 11(2), 145-179.

Larsson, J. P., Wennberg, K., Wiklund, J., \& Wright, M. (2017). Location choices of graduate entrepreneurs. Research Policy, 46(8), 1490-1504.

Lee, J., \& Win, H. N. (2004). Technology transfer between university research centers and industry in Singapore. Technovation, 24(5), 433-442.

Lehmann, E. E., \& Menter, M. (2017). Public cluster policy and performance. The Journal of Technology Transfer. https://doi.org/10.1007/s10961-017-9626-4.

Leyden, D. P. (2016). Public-sector entrepreneurship and the creation of a sustainable innovative economy. Small Business Economics, 46(4), 553-564.

Leyden, D. P., \& Link, A. N. (2015). Public sector entrepreneurship: US technology and innovation policy. Oxford: OUP Us.

Lin, B. W., \& Berg, D. (2001). Effects of cultural difference on technology transfer projects: An empirical study of Taiwanese manufacturing companies. International Journal of Project Management, 19(5), 287-293.

Lindholm Dahlstrand, A., \& Politis, D. (2013). Women business ventures in Swedish University incubators. International Journal of Gender and Entrepreneurship, 5(1), 78-96.

Link, A. N., \& Scott, J. T. (2013). Public R\&D subsidies, outside private support, and employment growth. Economics of Innovation and New Technology, 22(6), 537-550.

Link, A. N., Siegel, D. S., \& Bozeman, B. (2007). An empirical analysis of the propensity of academics to engage in informal university technology transfer. Industrial and Corporate Change, 16(4), 641-655.

McAdam, M., \& Debackere, K. (2018). Beyond 'triple helix' toward 'quadruple helix' models in regional innovation systems: Implications for theory and practice. $R \& D$ Management, 48(1), 3-6.

McAdam, M., Galbraith, B., McAdam, R., \& Humphreys, P. (2006). Business processes and networks in university incubators: A review and research agendas. Technology Analysis \& Strategic Management, $18(5), 451-472$.

Menter, M. (2016). Principal investigators and the commercialization of knowledge. In D. Audretsch, E. Lehmann, M. Meoli, \& S. Vismara (Eds.), University evolution, entrepreneurial activity and regional competitiveness (pp. 193-203). Berlin: Springer.

Meyer, M. (2006). Are patenting scientists the better scholars? An exploratory comparison of inventorauthors with their non-inventing peers in nano-science and technology. Research Policy, 35(10), 1646-1662.

Mian, S. A. (1996). Assessing value-added contributions of university technology business incubators to tenant firms. Research Policy, 25(3), 325-335.

Miller, K., Alexander, A., Cunningham J. A., \& Albats, E. (2017). Entrepreneurial academics and academic entrepreneurs: A systematic literature review. International Journal of Technology Management (forthcoming).

Miller, K., McAdam, R., \& McAdam, M. (2018). A systematic literature review of university technology transfer from a quadruple helix perspective: Toward a research agenda. $R \& D$ Management, 48(1), $7-24$.

Molas-Gallart, J. (1997). Which way to go? Defence technology and the diversity of 'dual-use'technology transfer. Research Policy, 26(3), 367-385.

Mosey, S., \& Wright, M. (2007). From human capital to social capital: A longitudinal study of technologybased academic entrepreneurs. Entrepreneurship Theory and Practice, 31(6), 909-935. 
Mowery, D. C. (2005). The Bayh-Dole Act and high-technology entrepreneurship in US universities: Chicken, egg, or something else? In G. D. Libecap (Ed.), University entrepreneurship and technology transfer (pp. 39-68). Bingley: Emerald Group Publishing Limited.

Mowery, D. C. (2011). Learning from one another? International policy "emulation" and university-industry technology transfer. Industrial and Corporate Change, 20(6), 1827-1853.

Mowery, D. C., Nelson, R. R., Sampat, B. N., \& Ziedonis, A. A. (2001). The growth of patenting and licensing by US universities: An assessment of the effects of the Bayh-Dole act of 1980. Research Policy, 30(1), 99-119.

Mowery, D. C., \& Sampat, B. N. (2004). The Bayh-Dole Act of 1980 and university-industry technology transfer: A model for other OECD governments? The Journal of Technology Transfer, 30(1-2), $115-127$.

Muscio, A. (2010). What drives the university use of technology transfer offices? Evidence from Italy. The Journal of Technology Transfer, 35(2), 181-202.

Nelson, R. R. (2001). Observations on the post-Bayh-Dole rise of patenting at American universities. The Journal of Technology transfer, 26(1), 13-19.

Nepelski, D., \& Piroli, G. (2017). Organizational diversity and innovation potential of EU-funded research projects. The Journal of Technology Transfer. https://doi.org/10.1007/s10961-017-9624-6.

Nicotra, M., Romano, M., Del Giudice, M., \& Schillaci, C. E. (2017). The causal relation between entrepreneurial ecosystem and productive entrepreneurship: A measurement framework. The Journal of Technology Transfer. https://doi.org/10.1007/s10961-017-9628-2.

O'Kane, C., Mangematin, V., Geoghegan, W., \& Fitzgerald, C. (2015). University technology transfer offices: The search for identity to build legitimacy. Research Policy, 44(2), 421-437.

O'Kane, C., Zhang, J. A., Cunningham, J. A., \& O'Reilly, P. (2017). What factors inhibit publicly funded principal investigators' commercialization activities? Small Enterprise Research, 24(3), 215-232.

O'Reilly, P., \& Cunningham, J. A. (2017). Enablers and barriers to university technology transfer engagements with small-and medium-sized enterprises: Perspectives of Principal Investigators. Small Enterprise Research, 24(3), 274-289.

Phillips, R. G. (2002). Technology business incubators: How effective as technology transfer mechanisms? Technology in Society, 24(3), 299-316.

Pitelis, C. (2012). Clusters, entrepreneurial ecosystem co-creation, and appropriability: A conceptual framework. Industrial and Corporate Change, 21(6), 1359-1388.

Plewa, C., Korff, N., Johnson, C., Macpherson, G., Baaken, T., \& Rampersad, G. C. (2013). The evolution of university-industry linkages-A framework. Journal of Engineering and Technology Management, 30(1), 21-44.

Ponomariov, B., \& Boardman, P. C. (2008). The effect of informal industry contacts on the time university scientists allocate to collaborative research with industry. The Journal of Technology Transfer, 33(3), 301-313.

Rasmussen, E., \& Rice, M. P. (2011). A framework for government support mechanisms aimed at enhancing university technology transfer: The Norwegian case. International Journal of Technology Transfer and Commercialisation, 11(1-2), 1-25.

Ratzinger, D., Amess, K., Greenman, A., \& Mosey, S. (2017). The impact of digital start-up founders' higher education on reaching equity investment milestones. The Journal of Technology Transfer. https:// doi.org/10.1007/s10961-017-9627-3.

Redondo, M., Redondo, M., Camarero, C., \& Camarero, C. (2017). Dominant logics and the manager's role in university business incubators. Journal of Business \& Industrial Marketing, 32(2), 282-294.

RezaeiZadeh, M., Hogan, M., O’Reilly, J., Cunningham, J., \& Murphy, E. (2017). Core entrepreneurial competencies and their interdependencies: Insights from a study of Irish and Iranian entrepreneurs, university students and academics. International Entrepreneurship and Management Journal, 13(1), $35-73$.

Rocha, H. O. (2004). Entrepreneurship and development: The role of clusters. Small Business Economics, 23(5), 363-400.

Rothwell, R., \& Dodgson, M. (1992). European technology policy evolution: Convergence towards SMEs and regional technology transfer. Technovation, 12(4), 223-238.

Secundo, G., De Beer, C., Schutte, C. S., \& Passiante, G. (2017). Mobilising intellectual capital to improve European universities' competitiveness: The technology transfer offices' role. Journal of Intellectual Capital, 18(3), 607-624.

Siegel, D. S., Veugelers, R., \& Wright, M. (2007). Technology transfer offices and commercialization of university intellectual property: Performance and policy implications. Oxford Review of Economic Policy, 23(4), 640-660. 
Siegel, D. S., Waldman, D., \& Link, A. (2003). Assessing the impact of organizational practices on the relative productivity of university technology transfer offices: An exploratory study. Research Policy, 32(1), 27-48.

Smith, D., Feldman, M., \& Anderson, G. (2017). The longer term effects of federal subsidies on firm survival: Evidence from the advanced technology program. The Journal of Technology Transfer https:// doi.org/10.1007/s10961-017-9633-5.

Spigel, B. (2017). The relational organization of entrepreneurial ecosystems. Entrepreneurship Theory and Practice, 41(1), 49-72.

Spigel, B., \& Harrison, R. (2017). Toward a process theory of entrepreneurial ecosystems. Strategic Entrepreneurship Journal. http://onlinelibrary.wiley.com/doi/10.1002/sej.1268/full.

van Stijn, N., van Rijnsoever, F. J., \& van Veelen, M. (2017). Exploring the motives and practices of university-start-up interaction: Evidence from Route 128. The Journal of Technology Transfer https://doi. org/10.1007/s10961-017-9625-5.

Watson, K., \& McGowan, P. (2017). Technology nascent entrepreneur experiences of start-up competition participation. In J. A. Cunningham \& C. O'Kane (Eds.), Technology-based nascent entrepreneurship (pp. 279-308). New York: Palgrave Macmillan.

Watson, K., McGowan, P., \& Cunningham, J. A. (2018). An exploration of the Business Plan Competition as a methodology for effective nascent entrepreneurial learning. International Journal of Entrepreneurial Behavior \& Research, 24(1), 121-146.

Winebrake, J. J. (1992). A study of technology-transfer mechanisms for federally funded R\&D. The Journal of Technology Transfer, 17(4), 54-61.

Worrell, E., Van Berkel, R., Fengqi, Z., Menke, C., Schaeffer, R., \& Williams, R. O. (2001). Technology transfer of energy efficient technologies in industry: A review of trends and policy issues. Energy Policy, 29(1), 29-43.

Wright, M., Siegel, D. S., \& Mustar, P. (2017). An emerging ecosystem for student start-ups. The Journal of Technology Transfer, 42, 1-14. 